\title{
Penumbuhan Lapisan Tipis Cooper Phthalocyanine (CuPc) Sebagai Bahan Dasar Sel Surya Organik
}

\author{
Fahru Nurosyid ${ }^{\star}$ ) dan Kusumandari \\ Jurusan Fisika, FMIPA, Universitas Sebelas Maret \\ Jl. Ir Sutami 36A. Surakarta 57126
}

Diterima 17-06-2009 Disetujui 18-08-2009

\begin{abstract}
Have been conducted a thin film plant of CuPc (Copper Phthalocyanine) and CuPc/Ag (Copper Phthalocyanine/ Argentum) at substrat ITO (Indium Tin Oxide) with evaporation method. Coat plant attenuate this use variation of mass that equal to $50 \mathrm{mg}, 100 \mathrm{mg}$, and $150 \mathrm{mg}$, with current deposition equal to 40 Ampere. Characterization of CuPc thin film use Scanning Electron Microscopy (SEM) to know the thickness of the thin film, UV - Visible Spectrophotometer to know absorbance value of CuPc thin film at wavelength of visible light, and measurement of voltage current by two point probe method to know the voltage current characteristics from the thin film in the dark situation and under illumination situation. From result of SEM characterization show the thickness value progressively along increase of CuPc materials mass. For the each deposition mass obtained thickness value $(0,46 \pm 0,01)$ until $(0,92 \pm 0,02) \mu \mathrm{m}$. UV - Visible Spectrophotometer characterization show light absorption by CuPc thin film layer in visible light, absorption happened at wavelength range $520 \mathrm{~nm}$ until $780 \mathrm{~nm}$. From the current voltage measurement at dark and under illumination situation obtained a current value progressively increase along its mass increase, but decrease from illuminated to darkness.
\end{abstract}

Keywords: absorbance, Copper Phthalocyanine, current-voltage measurement

\section{PENDAHULUAN}

Teknologi fotovoltaik merupakan teknologi yang menggunakan sinar matahari untuk memperoleh secara langsung tenaga listrik arus searah. Teknologi fotovoltaik menggunakan divais semikonduktor yang disebut sel surya (Sopian 2003). Pembangkitan listrik ini termasuk teknologi yang ramah lingkungan karena tidak menggunakan bahan bakar. Sumber energinya sendiri yaitu matahari yang sifatnya tidak pernah habis, sehingga teknologi ini digolongkan sebagai teknologi pembangkitan energi listrik yang terbarukan dan ramah lingkungan.

Di samping itu dengan teknologi ini, listrik dapat dibangkitkan langsung di tempat yang dibutuhkan asalkan ada sinar matahari. Dengan demikian dapat menghilangkan kebutuhan akan penggunaan jalur transmisi kabel listrik dengan infrastruktur yang sangat mahal. Teknologi fotovoltaik juga tidak menyertakan mesin mekanik yang berputar, sehingga proses pemeliharaannya menjadi mudah dan murah (Konagai 2000).

Selain itu pula kelebihan teknologi fotovoltaik antara lain energi yang disediakan tersedia melimpah

\footnotetext{
*Telp: 0271669017

Email: nurosyid@yahoo.com
}

dan diperoleh secara cuma-cuma, bekerja tanpa suara dan tidak berdampak negatif terhadap lingkungan dan dapat bekerja secara otomatis.

Kendala utama dalam usaha pemanfaatan teknologi fotovoltaik adalah harganya yang sangat mahal dibandingkan dengan listrik konvensional. Dari keseluruhan komponen biaya dalam proses pemasangan sistem fotovoltaik, sel surya merupakan komponen termahal yaitu sekitar $70 \%$ dari keseluruhan harga komponen pendukung dan biaya pemasangan.

Mahalnya sistem fotovoltaik disebabkan oleh kebutuhan lahan yang sangat luas untuk menghasilkan daya maksimal. Intensitas sinar matahari yang sampai ke bumi sekitar $1.000 \mathrm{watt} / \mathrm{m}^{2}$. Sedangkan efisiensi maksimal yang dihasilkan oleh sel surya dengan bahan silikon kristal tunggal baru mencapai $25 \%$, sehingga produksi listrik maksimal yang dapat dihasilkan oleh pembangkitan sistem fotovoltaik hanya mencapai 25 watt $/ \mathrm{m}^{2}$ (Alamanda D 1997).

Sedangkan bila dilihat dari materialnya, material dengan struktur kristal tunggal misalnya silikon yang banyak digunakan dalam pembuatan sel surya masih sangat mahal. Hal ini karena biaya pembuatan material dengan struktur kristal tunggal cukup sulit, sehingga 
biaya produksi secara keseluruhan dalam pembuatan sel surya akan mahal. Namun di lain sisi, efisiensi yang diperoleh dari sel surya kristal tunggal ini secara teoritis bisa mencapai 40\% (Umeno 1997).

Selain itu, ada alternatif material lain menggunakan bahan organik yang mempunyai peluang dapat diproduksi sebagai sel surya dengan biaya yang murah.

Akan tetapi, efisiensi sel surya organik struktur tersebut mempunyai efisiensi yang masih rendah. Sampai saat ini efisiensi maksimum yang dicapai oleh sel surya organik adalah 3,5\% (Takhashi et al., 2000).

Usaha-usaha peningkatan efisiensi sel surya organik terus dilakukan sejak dua puluh tahun terakhir (Tang 1986). Rendahnya efisiensi sel surya organik disebabkan oleh panjang difusi exciton $L_{d^{*}}$ Parameter ini lebih mendominasi dibandingkan dengan panjang absorpsi optik (Yakimov 2002). Oleh karena itu, untuk meningkatkan efisiensi sel surya organik dapat dilakukan dengan memperhatikan fenomena disosiasi dari eksiton di daerah aktif. Bila terjadi disosiasi dari exciton, maka akan terbentuk pasangan elektron dan hole yang dapat memberikan kontribusi terhadap peningkatan efisiensi sel surya.

Proses operasi dari sel surya organik terdiri dari 3 tahapan, yaitu (a) absorpsi cahaya surya (energi foton), (b) terjadinya pemisahan muatan (elektron dan hole) pada permukaan antara donor-akseptor, dan (c) aliran dari kedua muatan tersebut di dalam bahan organik (bulk) ke kedua elektrodanya. Syarat yang harus dipenuhi untuk mendapatkan efisiensi yang tinggi pengubahan energi foton (cahaya) menjadi arus listrik adalah bahwa elektron dan hole tidak terjadi rekombinasi (bersatu) sebelum dibawa/dialirkan ke rangkaian eksternal. Untuk mengurangi proses rekombinasi elektron-hole, maka elektron dan hole ditransportasikan (dibawa) oleh bahan yang yang berbeda. Sebagai contoh untuk piranti donor-akseptor, maka material akseptor mempunyai sifat konduktivitas elektron yang baik. Sebaliknya untuk bahan donor mempunyai konduktivitas hole yang baik. Oleh karena itu bahan organik yang mudah menghasilkan pasangan elektron-hole dan bahan organik mobilitas muatan yang tinggi adalah merupakan faktor yang penting dalam menentukan besarnya efisiensi sel surya bahan organik.

Karena kebutuhan transport muatan di dalam piranti organik, maka adanya hubungan yang kuat antara efisiensi dan morfologi. Kualitas dan homogenitas bahan organik yang digunakan akan menyebabkan efisiensi yang semakin tinggi dari sel surya. Bahan organik sel surya yang tidak homogen dengan lapisan yang terdapat lubang-lubangnya dan resistivitas seri (serial resistivity) akan menyebabkan "faktor pengisi" ( $F F$ : fill factor) kecil, penguatan kecil dan dan tegangan rangkaian-terbuka $\left(V_{O C}\right)$. Sebagai tambahan bahwa dengan semakin tipis ketebalan piranti (devices) pada nilai optimum, maka efisiensi sel surya dapat naik dengan nilai yang cukup berarti (Fromherz et al., 2000). Untuk mendapatkan suatu lapisan tipis bahan organik sel surya, maka proses deposisi dengan kontrol yang baik harus dilakukan. Kenaikkan efisiensi sel surya terutama efisiensi kuantum untuk fotogenerasi dari pembawa muatan (carriers) adalah suatu topik kunci dalam kajian sel surya bahan organik yang akan digunakan dalam kegunaan yang praktis.

Efisiensi sel surya organik dapat ditingkatkan dengan cara mengendalikan exciton supaya dapat terpecah dengan cepat. Hal ini karena optimasi struktur sel surya organik, juga optimasi terhadap mekanisme pemecahan exciton menjadi pasangan elektron dan hole adalah penting. Dalam penelitian ini akan dilakukan kajian penumbuhan cooper phthalocyanine dengan variasi ketebalan untuk mendapat suatu disain sel surya organik yang murah dan berefisiensi tinggi dengan struktur ITO/CuPc/Ag dan memperoleh informasi mengenai parameter-parameter yang bertanggung jawab terhadap peningkatkan efisiensi sel surya ITO/ CuPc Ag.

\section{METODE PENELITIAN}

Alat penelitian mencakup: vacuum evaporation, Furnace Nabertherm Model S27, XRD Simadzu R500, SEM Model JEOL, LCZ meter Model 2343, Lock-In Model SR 530, tabung reaksi, pipet, gelas Becker, Ultrasonic Model Branson 2210, seperangkat osciloskop dan signal generator, four point probe, UVVis-IR spectrophotometer, furnace, dan coating unit (evaporator system vakum). Bahan penelitian mencakup Kuprum phthalocyanine (CuPc), substrat dari lapisan Indium Tin Oxide (ITO).

Lapisan Tipis CuPc dideposisi dengan evaporator. Dalam optimasi evaporator dilakukan variasi massa CuPc yang dideposisi dari $50 \mathrm{mg}, 100 \mathrm{mg}$, dan $150 \mathrm{mg}$ diharapkan menghasilkan variasi ketebalan lapisan tipis yang terbentuk. Sedang arus elektroda yang digunakan sebesar $40 \mathrm{~A}$. 

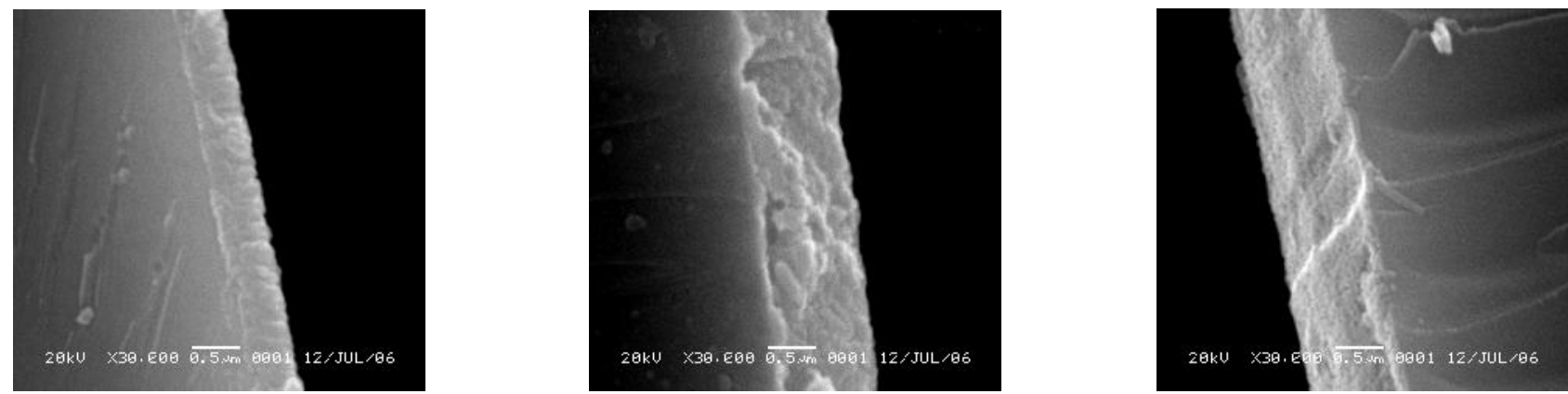

Gambar 1. Hasil foto SEM tampang lintang lapisan CuPc dengan variasi massa CuPc yang dideposisi (a. massa 50 mg; b. $100 \mathrm{mg}$; $150 \mathrm{mg})$
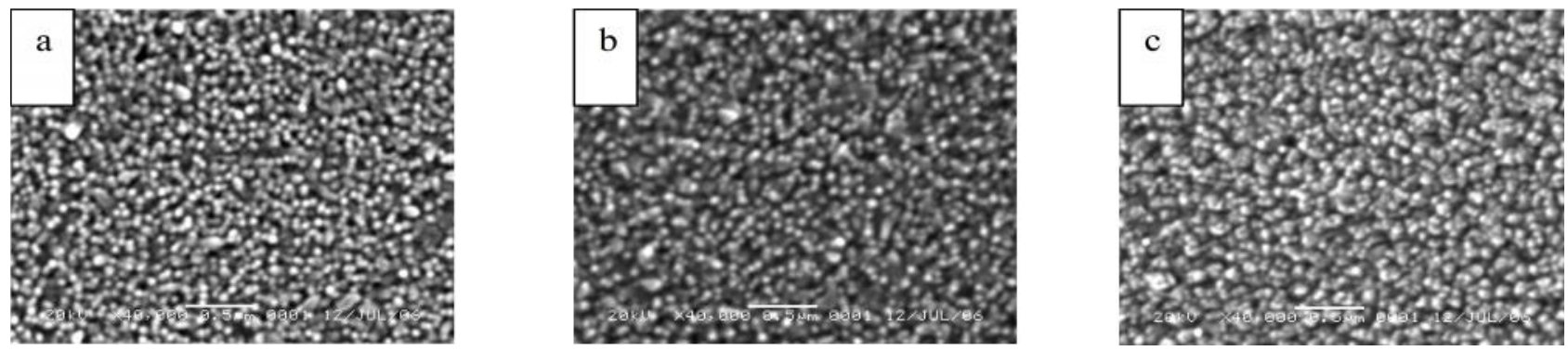

Gambar 3. Bentuk morfologi permukaan lapisan tipis CuPc variasi massa evaporator ( a. Massa 50 mg; b. massa 100mg; c. Massa $150 \mathrm{mg}$

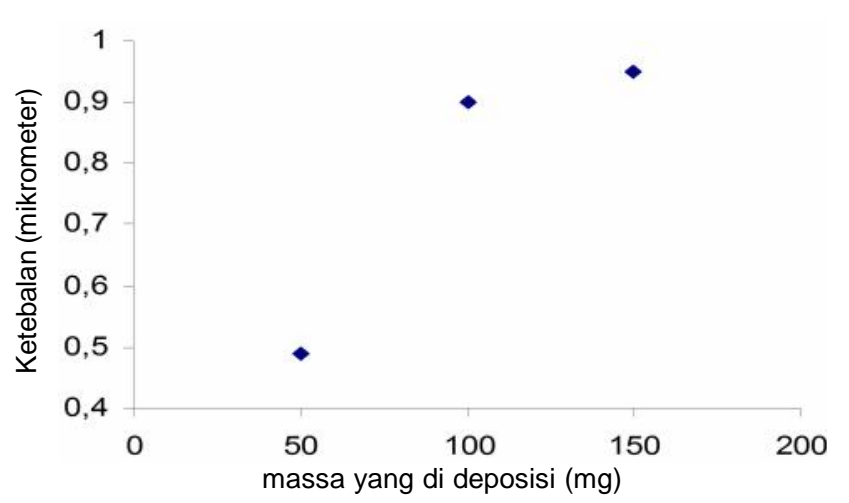

Gambar 2. Grafik ketebalan terhadap massa deposisi

Lapisan tipis CuPc dikarakterisasi meliputi sifat fisis, sifat optik dan sifat listrik Karakterisasi sifat fisis adalah pengujian morfologi permukaan dengan SEM (scanning electron Microscope), ketebalan lapisan CuPc yang dideposisi. Kemudian sifat optik menggunakan UV-Vis Spectrometer dan uji photorespon dengan pengukuran I-V dalam keadaan terang atau gelap.

\section{HASIL DAN PEMBAHASAN}

\section{Pengukuran Ketebalan Lapisan CuPc.}

Pengukuran ketebalan dilakukan dengan melihat tampang lintang lapisan tipis dengan SEM (Gambar 1). Teramati secara jelas bahwa semakin lama banyak massa yang dideposisi maka ketebalan lapisan tipis meningkat.
Dari hasi Foto SEM tampak tampang lintang lapisan menunjukan ketebalan lapisan yang terdeposisi pada subtrat ITO dan dari pengukuran ketebalan diperoleh bahwa semakin banyak massa yang diposisi semakin tebal lapisan yang terbentuk (Gambar 2).

Analisis Morfologi Permukaan Lapisan Tipis. Untuk mengetahui tingkat kerataan lapisan tipis yang terbentuk maka dilakukan pemotretan dengan SEM. Dari Gambar 3 terlihat morfologi permukaan lapisan rata dan homogen. Variasi massa yang dilakukan tidak mempengaruhi bentuk morfologi secara signifikan.

Analisis Sifat Optik. Pengujian sifat optik (dalam hal ini absorbansi) lapisan tipis CuPc menggunakan UV-Vis spectrophotometer buatan shimadzu dengan panjang gelombang antara 400-800 nm dengan kenaikan panjang gelombang $1 \mathrm{~nm}$. Hasil pengujian ditampilkan pada (Gambar 4). besarnya absorbansi sebanding dengan massa bahan yang dideposisikan dan ketebalan lapisan yang terbentuk.

Tampak nilai absorbansi lapisan CuPc berada pada rentang cahaya tampak (visibel light). Serapan terjadi pada range panjang gelombang antara $520-780 \mathrm{~nm}$. Dengan meningkatnya ketebalan lapisan maka nilai absorbansinya juga semakin meningkat. Hal ini disebabkan nilai absorbansi sebanding dengan massa bahan pendeposisi dan kebelan bahan, karena bahan yang lebih tebal jumlah atom atau molekuang menyerap cahaya juga semakin banyak. 


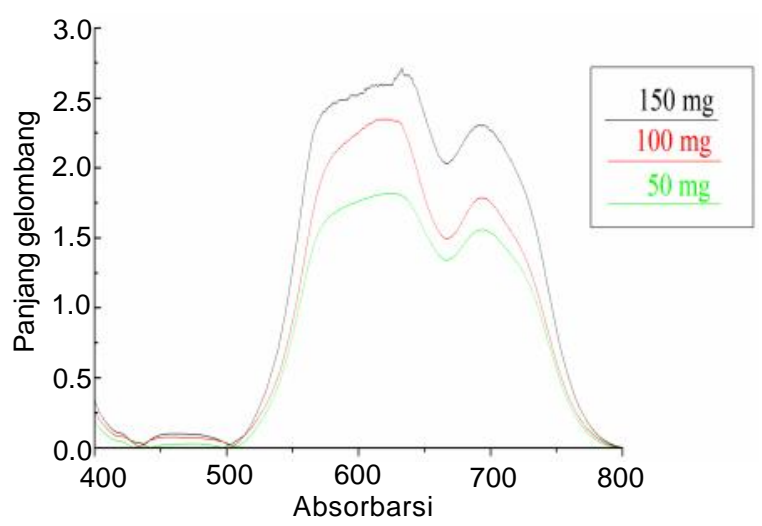

Gambar 4. Grafik absorbansi ITO/CuPc berdasarkan massa CuPc

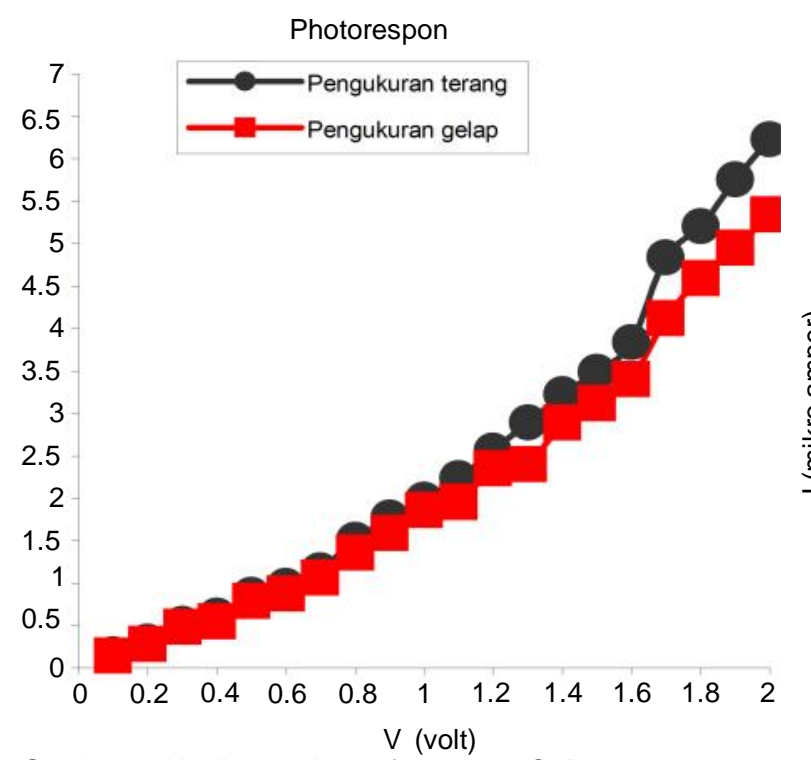

Gambar 6. Hasil pengukuran fotorespon CuPc massa $50 \mathrm{mg}$, arus $40 \mathrm{~A}$

Dari Gambar 5 terlihat pada massa $50 \mathrm{mg}$ terdapat dua puncak pada panjang gelombang $629 \mathrm{~nm}$ dan pada puncak $695 \mathrm{~nm}$ dengan puncak pertama lebih tinggi dibanding puncak kedua. Pada massa $100 \mathrm{mg}$ dan 150 mg nampak adanya puncak rata antara panjang gelombang 550-740 nm. Penyerapan cahaya oleh lapisan merata pada panjang gelombang 550-740 nm. Fenomena ini terjadi dimungkinkan karena adanya unsur lain atau pengotor yang terdeposisi pada lapisan ini dapat dilihat dari hasil uji Energy dispersive $X$-ray (EDX) (Gambar 5). Gambar 5a menunjukkan pada massa $50 \mathrm{mg}$ pengotor yang ada hanya $\mathrm{O}$ ini dimungkin adanya oksidasi oleh udara terbuka. Pada gambar $5 b$ dan $5 \mathrm{c}$ nampak adanya unsur lain seperti $\mathrm{O}, \mathrm{Al}, \mathrm{Si}$, dan Ca.

Dilihat dari sifat absorbansi lapisan CuPc ini sangat mendukung sebagai bahan sel surya, karena lapisan ini meyerap sinar dengan panjang gelombang cahaya tampak yang merupakan cahaya matahari.
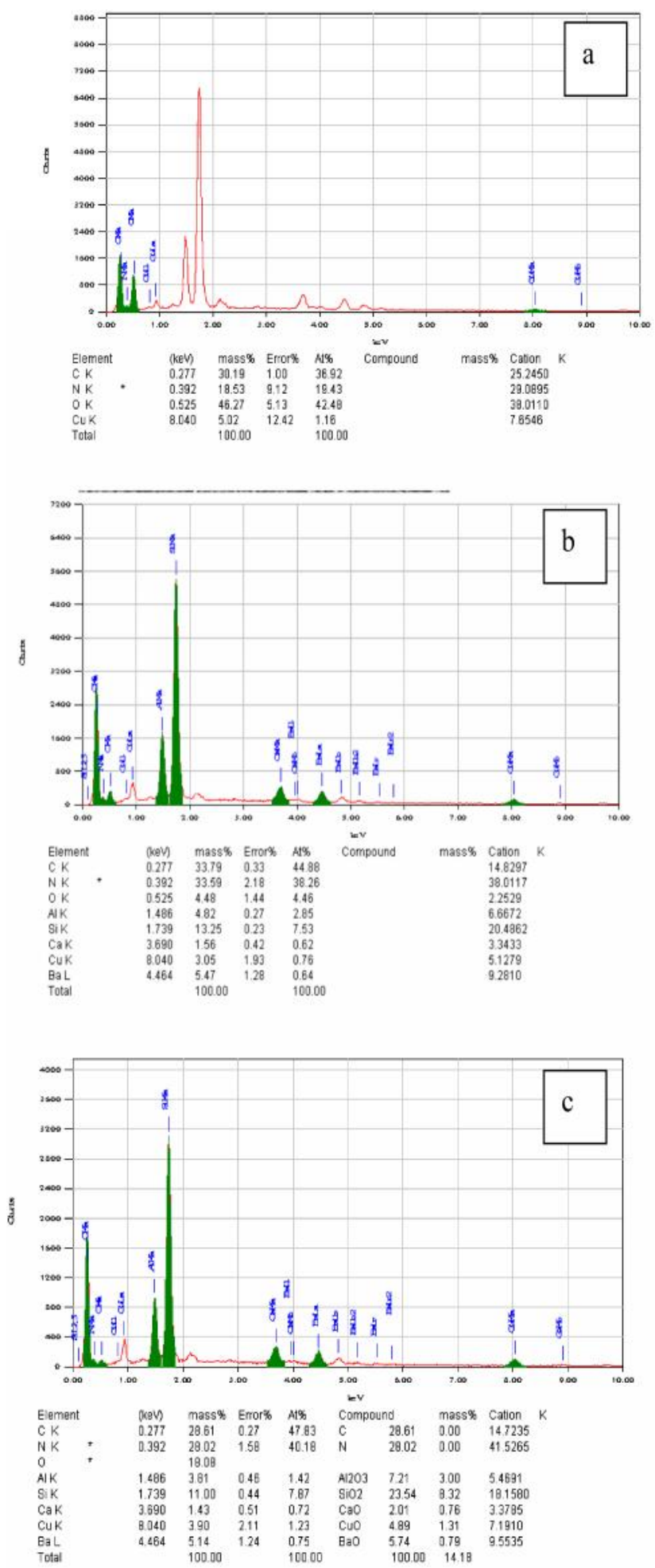

Gambar 5. Hasil uji komposisi variasi massa dengan EDX a) 50mg; b) $100 \mathrm{mg}$ dan c) $150 \mathrm{mg}$

Namun apakah penyerapan ini menghasilkan listrik yang baik masih perlu adanya pengujian lebih lanjut .

Analisis Sifat Listrik. Pengukuran fotorespon dilakukan dengan mengukur I-V pada saat gelap atau tidak disinari dan pada saat terang atau disinari cahaya lampu neon. (Gambar 6) merupakan hasil pengukuranfotorespon, tampak pada saat terang arus yang terukur lebih tinggi dari pada saat lapisan CuPc 
diukur saat gelap. Hal ini dapat dipahami karena bahan metal organik menyerap cahaya tampak. Fenomena ini dapat dibuktikan dari uji sifat optik pada (Gambar 4). Ketika cahaya atau foton terserap maka akan terjadi eksitasi elektron sehingga terbentuk hole atau kekosongan. Semakin banyak hole yang terbentuk arus yang terukur juga semakin besar. Sehingga ketika lapisan di kenai cahaya arus yang terukur lebih besar.

\section{KESIMPULAN}

Dari hasil penelitian yang telah dilakukan maka dapat diambil kesimpulan bahwa dengan adanya penambahan massa yang dideposisi ketebalan lapisan yang terbentuk juga semakin meningkat. Berdasarkan foto SEM tampak morfologi permukaan lapisan rata dan homogen, variasi massa bahan deposisi yang dilakukan tidak mempengaruhi bentuk morfologi secara signifikan. Berdasarkan uji UV-Vis spectrophotometer nilai absorbansi lapisan CuPc berada pada rentang cahaya tampak (visibel light), serapan terjadi pada range panjang gelombang antara 520-780 nm. Dari pengukuran Photorespon diperoleh hasil pada saat terang arus yang terukur lebih tinggi dari pada saat lapisan CuPc diukur saat gelap.
UCAPAN TERIMA KASIH

Kami mengucapkan terima kasih kepada Direktorat Jendral Pendidikan Tinggi Departemen Pendidikan Nasional, yang telah membiayai Penelitian ini lewat dana Hibah Bersaing dengan Nomor Kontrak : 017/SP2H/PP/DP2M/III/2008.

\section{DAFTAR PUSTAKA}

Almanda, D. 1997, Prospek PLTS di Indonesia, Elektro Indonesia, Edisi ke 10, November 1997, dalam http:// www.elektroindonesia.com/elektro/energi10.html

Fromherz, T. F., Panginer, D. Gebeyehu, C. Brabec, J.C, Hummalen, N.S. \& Sariciftci. 2000, Sol. Energy Mater. Sol. Cells, 63.61

Konagai, M. 2000, Lesson for Twenty-First Century Partnerships, Paris, France, October 2000.

Sopian, K. 2003, Harnesing the sun:solar energy research and development in Universiti Kebangsaan Malaysia, Proc. of The $2^{\text {nd }}$ Kentingan Physics Forum, 1: 9.

Takahshi, K. N. Kuraya, T. Yamaguchi, T komura, K. \& Murata. 2000, Three-layer Organic Solar Cell With HighPower Conversion Efficiency of $3.5 \%$, Solar Energy Materials \& Solar Cells, 61: 403-416

Tang, C.W. 1986, Two Layer Organic Photooragic Cells. Appl. Phys. Lett, 48: 183-186.

Umeno, M. 1997, "Toward Efficiency of 40\%", Proc. of JapanIndonesia Joint Seminar on Photovolaics, Institute of Technology Bandung, 1:8.

Yakimov, A. 2002, High Photovoltage Multiple-heterojunction Organic Solar Cells Incorporating Interfacial Metallic Structure, Appl. Phys Lett, 80: 1667-1669. 